\title{
International Cooperation in the Fight against Tax Evasion
}

\author{
Roman Vybíral*
}

\begin{abstract}
* JUDr. Roman Vybíral, PhD, Assistant Professor of Financial Law and Financial Science, Department of Financial Law and Financial Science, Faculty of Law, Charles University, the Czech Republic. The author specialises in tax law and insurance law. He is the author or co-author of more than 30 reviewed articles and books. He is an attorney-at-law and a member of the Centre of Information and Organization of Public Finances and Tax Law Research in Central and Eastern Europe. This paper has been elaborated within the programme "PROGRES Q02 - Publicization of Law in the European and International Context" which is realized in 2019 at the Faculty of Law of the Charles University. ORCID: 0000-0002-1112-408X. (e-mail: vybiralr@prf.cuni.cz)
\end{abstract}

\begin{abstract}
As regards the fight against tax evasion individual states do not act isolated, on the contrary the key role is being played by international organisations. Because of the wide fiscal sovereignty of states such cooperation takes many forms and outputs. On the one hand, this article aims to identify areas within which the fight against tax evasion occurs. Furthermore, it aims to analyse the development and current status of important international organisations that fight against tax evasion and to present their selected outputs.
\end{abstract}

Keywords: tax evasion; international organisation; OECD; European Union

\section{Introduction}

At the begging, it is necessary to outline the not very clear relationship between the terms tax evasion, tax optimisation, law abuse, circumvention of law, aggressive tax planning and other such terms. Although it may look like a considerably unclear group of terms, from a purely theoretical viewpoint, it is mainly just about labelling concrete practices as legal and the others as illegal. However, it is clear that to define such boundaries is not only difficult, but also under the current circumstances, I dare to say, impossible. This is the reason why there are many practices that could be identified as lying somewhere at the edge of legal and illegal. The borderline between the legal and illegal practices is sometimes being deduced based on the decision-making practice of courts in the particular countries. Given the fact that for a long period of time, the countries on the field of international tax law are not performing separately and that they cooperate firstly on the basis of legally binding exchange of information, and secondly on more or less unbinding cooperation in the area of sharing knowledge and practices that aim to improve the efficiency of the fight against tax evasion, as a result, international organisations play a key role in the area of fighting tax evasion, even though international organisations frequently produce solely unbinding and recommending measures and conclusions. ${ }^{1}$ Then it is often upon the particular countries to reflex these 
unbinding conclusions into their domestic legislation and decision-making practice in order to make the fight against tax evasion more efficient. This paper deals with the issue of this international cooperation, and apart from a brief outline of historical development, it is also analysing current positions of particular significant international organisations or political coalitions, ${ }^{2}$ which have covered the fight against tax evasion on their agendas.

\section{Definition of the Area of the Fight against Tax Evasion}

This part describes the areas in which tax evasion occurs or have occurred. As it was stated in the introduction, the classification of the term "tax evasion" in the tax law is nearly as unclear as is the definition of the term. It is not the aim of this paper to define tax evasion - that have been tried by many legal scholars throughout history. ${ }^{3}$ The area of tax evasion is quite broad, and of course the tools to prevent tax evasion respond to this accordingly.

\subsection{Double tax treaties}

In the international context, there are situations when the factually generated income, which would under standard circumstances be subject to taxation, cannot be taxed at all in either of the countries when appropriately using some particular processes (e.g. when the place of residency of the subject is modified etc.), especially in cases when there is a double taxation international treaty (resp. double tax treaty) between the two particular countries. ${ }^{4}$ Therefore, using gaps and loopholes may not result in double taxation, but in no taxation at all. We can observe this issue more and more often nowadays and operations that aim to cover and modify decisive facts to minimalise tax are highly-developed and more difficult for tax administrators to resolve. Both unilateral domestic and international measures have two roles in international tax law. On the one hand, these measures arise from its initial fundamentals, which consists in elimination of multiple tax, on the other hand, the authorities must deal with using the shortcomings of the measures in order to minimalise tax, especially in the last decades. It is clear that playing these two roles at the same time can be difficult. The Organisation for Economic Co-operation and Development (hereinafter referred to as "OECD") and the United Nations (hereinafter referred to as "UN") are the key international organisations in this field.

\subsection{Exchange of information between tax administrators}

Another area of cooperation in the fight against tax evasion is exchange of information between the tax administrators from different countries; its aim is to make a picture of the whole situation using partial information, that as such would not be sufficient to reveal and "prosecute" tax evasion. The issue of information exchange is often included in the double taxation treaties. Between the countries that are not parties to such treaties, the bipartial treaties concerning information exchange in tax issues play an important role. In the 
area of information exchange between tax administrators, the OECD, the European Union, the UN and the Council of Europe play a key role.

\subsection{Other areas of international cooperation}

Apart from the stated areas, there is a wide range of other levels of cooperation. Often it can be the publishing of unbinding reports and recommendations that aim to raise the awareness of efficient procedures to prevent tax evasion that the particular countries voluntarily include into their legislation or administrative practice. Furthermore, cooperation can also be realised on a political level, which means that lists of (un) cooperating countries concerning information exchange and prevention of tax evasion are being issued, these countries can be labelled as so called tax havens. As it was stated above, these lists have an impact primarily on the political and not on the legal level. Moreover, in the context of the fight against tax havens, it is noteworthy to mention the particular "quasi-cooperation" in a form of transposing instruments from other jurisdictions into its own legislation. An example of this measure may be an introduction of higher tax rate on the incomes that are to be subject to tax in the tax havens. "Coming into force on $1^{\text {st }}$ of January 2013 in section 36 (1) (c) Act no. 586/1992 Coll., Code on Taxation on Income, there is [...] introduced 35\% withbolding tax rate [...], which applies, in short, when paying income to tax non-residents who are not residents of other European Union member states or European Economic Area member states or non-residents of a country that have entered into a double taxation treaty with the Czech Republic or an agreement on concerning information exchange in tax matters [...]." We could find many such activities or similar ones in the field of international tax law. Usually they are rather informal recommending instruments powered by political power, which is a result of tax sovereignty of particular countries.

\section{The Role of Particular International Organisations and Groups}

This chapter is dealing with international organisations which play a key role in the fight against tax evasion, and the outcomes of these organisations. Given the fact that many of the partial instruments are rooted deeply in the past, it is not very convenient to organise the particular subchapter into two periods (history and contemporary state), so the topic will be discussed comprehensively.

\subsection{OECD}

This organisation has created many interpretation and recommending manuals during the decades, which were more or less accepted by the developed world economies. Due to the nature of this organisation, its main outcomes are researches and recommendations without direct international binding effect which are being afterwards reflected by domestic measures of particular countries. This is the largest difference between the OECD instruments and for 
example the European Union instruments, whose instruments may be legally binding. On the other hand, it is important to add that the OECD's political influence is so important in this field, that the member states do accept its conclusions and reflect them in their domestic legislation. In this matter is the role of the OECD quite specific. Should we mention the particular research, it would be the one entitled Harmful Tax Competition - An Emerging Global Issue 6 from 1998 or a more recent research entitled The Global Forum on Transparency and Exchange of Information for Tax Purposes ${ }^{7}$ from 2012.

Furthermore, the OECD in its regular reports presents (or have presented) the imaginary black, grey and white list of countries, depending on their willingness to cooperate on international level in information exchange in tax matters. On the black list there are (or were) jurisdictions that refuse any international cooperation in information exchange in tax matters, on the grey list there are jurisdictions that take first steps towards cooperation, and on the white list there are listed jurisdictions that fully cooperate. The examination of these issues takes place on two levels. The first level concerns the existence of the legal framework for information exchange and transparency. The second level deals with the practical functioning of the legal framework in practice.

A current issue that the OECD is dealing with is the issue of base erosion and profit shifting. Following the meeting of the Ministers of Finance and Governors of the central banks of the so called G20 (the Group of Twenty), the OECD issued the common Action Plan, ${ }^{8}$ which is in many ways inspired by the previous document issued solely by the EOCD. ${ }^{9}$ At the following meeting of the G20 Group, the parties also came to a partial conclusion that the content of the Action Plan, which is primarily concerning double taxation, artificially reducing tax base and shifting profits to more convenient jurisdictions, must be strictly obeyed. The Action Plan contains 15 partial points that must be in a considerably short time dealt with. ${ }^{10}$

On the $1^{\text {st }}$ of February 2014, the multilateral Convention on Mutual Administrative Assistance in Tax Matters came into force. The convention was prepared under the auspices of the OECD and the Council of Europe and has been open to a signature since 1998. On the $1^{\text {st }}$ of June 2012, a protocol came into effect which amends the convention and puts it in line with the new OECD standards for information exchange in tax area. The convention amended by the protocol represents a comprehensive multilateral tool developed by the cooperation of the Council of Europe and the OECD that enables all forms of international administrative cooperation that are stated in annex $\mathrm{A}$ of the convention. ${ }^{11}$

\subsection{The European Union}

Concerning documents passed by the European Union (or its predecessor), they can be categorised into two levels. The first level is made up of legally binding documents, typically in a form of secondary European Union law. The second level contains unbinding documents (whatever they are called) which function just as a recommending lead, however, they have a significant impact on the interpretation of the binding rules. Both levels are undoubtedly important. Concerning the binding documents, it is necessary to mention Directive 2011/16/EU on administrative cooperation in the field of taxation and repealing Directive $77 / 799 /$ EEC10 that covers the information exchange between the tax 
administrators in the member states. A significant document on the second level is the so called Action Plan to strengthen the fight against tax fraud and tax evasion from December 2012. ${ }^{12}$ Apart from the evaluation of the current state, it contains a list of particular measures which should be reached in a short or long term. ${ }^{13}$ In March 2015, the European Commission issued a package which aims to raise tax transparency in the area of income tax of legal entities. It mentions, for example, the obligation of the tax administrators to exchange the particular tax decision and other aspects that aim to limit tax evasion. A part of the package is the call for revising the Code of Conduct for Business Taxation from $1997,{ }^{14}$ in which the countries have committed themselves not to introduce new potentially harmful tax measures and to limit existing measures of this nature.

\subsection{Other international organisations}

To provide the readers with a full picture, it is necessary to at least briefly mention that the particular activities related to the fight against tax evasion take place in other political groups, for example the countries of the so called G8 (the Group of Eight) ${ }^{15}$ or the already mentioned G20; once again, they solely issue recommendations that are not legally binding. Other activities take place in the Council of Europe, as it was stated above. Last but not least, it is important to point out the UN activities. ${ }^{16}$ Worldwide, there are tens of other, often local organisations, and the roles and documents they issue fairly differentiate between each other. Some countries are involved in almost no international cooperation; these are very often the so called tax havens. There are none but political sanction threats for them especially due to the still wide tax sovereignty.

\section{Conclusion}

To sum up, although some international organisations (typically the OECD) have played a significant role in the area of the fight against tax evasion, it can be said that their influence have consisted solely on the political level, which is a result of the nature of these organisations that are not able to pass a binding legal rule. Even though the outcomes are not binding, their documents have a strong impact on the domestic legal frameworks of (not only) its member states. Apart from the OECD, there are other organisations whose impact lays mainly on the political level, these are the G8, the G20, the UN or the Council of Europe. The most important actor nowadays which can pass legally binding documents is the European Union. Cooperation between the member states against tax evasion takes place primarily on the procedural level (information exchange between the tax administrators), as well as on the substantial level, on which many documents with various names were passed (researches, reports etc.), which have no binding effect, however, they play a key role concerning the interpretation and application of the binding norms of the European Union law. In the previous years the tendencies to fight tax evasion have increased within practically all international organisations, however, any rapid development is hardly to happen in the following years. 


\section{References}

1 Not exclusively; some measures adopted within the European Union can be used as an example (as discussed below).

2 The single abbreviation "international organisation" will be used in the text.

3 See e.g. Kevin Prosser, Rebecca Murray, Tax Avoidance, 2 et seq. (London, Sweet \& Maxwell, 2012).

4 For more details see Michael Lang, Introduction to the Law of Double Taxation Conventions, $2^{\text {nd }}$ edition, 35 (Amsterdam, IBFD, 2013).

5 See Informace Generálního finančního ředitelstvi k prokázáni daňové rezidence u fyzických a právnických osob pro úcely stanoveni srážkové danè [Information of the General Financial Directorate to prove tax residency for natural and legal persons for the purpose of determining withholding tax], www.financnisprava.cz/assets/ cs/prilohy/d-seznam-dani/srazkova_dan.pdf (accessed 26 May 2018).

6 See Harmful Tax Competition - An Emerging Global Issue, www.uniset.ca/microstates/oecd_44430243.pdf (accessed 21 May 2018).

7 See The Global Forum on Transparency and Exchange of Information for Tax Purposes, www.oecd.org/ctp/ harmful/43757434.pdf (accessed 21 May 2018).

8 See Action Plan on Base Erosion and Profit Shifting, www.oecd-ilibrary.org/taxation/action-plan-on-baseerosion-and-profit-shifting_9789264202719-en (accessed 24 May 2018). DOI: http://dx.doi.org/10.1787 19789264202719-en

9 See Addressing Base Erosion and Profit Shifting, www.oecd-ilibrary.org/taxation/addressing-base-erosionand-profit-shifting_9789264192744-en (accessed 21 May 2018). DOI: http://dx.doi.org/10.1787/ 9789264192744-en

10 For more details see Action Plan on Base Erosion and Profit Shifting, www.oecd.org/ctp/BEPSActionPlan. pdf (accessed 26 May 2018). DOI: http://dx.doi.org/10.1787/9789264202719-en

11 See Úmluva o vzájemné správni pomoci v dañových záležitostech [Convention on Mutual Administrative Assistance in Tax Matters], www.mfcr.cz/cs/legislativa/mezinarodni-vymena-info-v-danove-oblasti/umluvao-vzajemne-spravni-pomoci-v-danov (accessed 15 May 2018).

12 See An Action Plan to strengthen the fight against tax fraud and tax evasion, https://ec.europa.eu/taxation customs/sites/taxation/files/resources/documents/taxation/tax_fraud_evasion/com_2012_722_en.pdf (accessed 25 May 2018).

13 In the conclusion it is stated that "This action plan identifies a series of specific measures which can be developed now and in years to come. [...] In order to ensure that the actions described in this action plan will be duly implemented, the Commission will put in place appropriate monitoring and scoreboards, which includes in particular regular exchanges of views in relevant committees and working groups on the basis of detailed questionnaires."

14 See The Code of Conduct for Business Taxation, www.consilium.europa.eu/en/council-eu/preparatory-bodies/ code-conduct-group (accessed 27 May 2018).

15 For more details see e.g. Michele Fratianni, John Kirton, Paolo Savona, Financing Development: The G8 and UN Contribution (Aldershot, Ashgate Publishing, 2007).

16 See e.g. The ECOSOC discussion on "International Cooperation in Tax Matters", www.un.org/esa/ffd/wpcontent/uploads/2014/08/2013_6TaxNewsletter.pdf (accessed 28 June 2018). 